\title{
EFFICIENCY OF BACTERIAL LYSATES IN MULTIMODALITY THERAPY OF CHILDREN OF EARLY AGE WITH VIRAL CROUPS
}

\section{T.A. Kirsanova, S.V. Kuznietsov, M.S. Zimina, E.V. Suprun}

\begin{abstract}
The paper presents the results of studying the features of the cytokine status and indicators of local immunity of children with acute respiratory viral infection, proceeding with the manifestations of the syndrome of croup, and an evaluation of the efficiency of using bacterial lysates in a multimodality treatment of patients. It has been corroborated that edematous and hypersecretory variants of croup proceed against a background of a considerable intensification of a systemic inflammatory response and a decrease of the factors of local immunity; whereas the spasmodic variant - develops against a background of the physiologic level of cytokines and an increase of the factors of local immunity in the acute period of the disease. The use of bacterial lysates in multimodality therapy of patients with the edematous variant of the syndrome of croup is accompanied with an insignificant decrease in the level of cytokines, whereas with the hypersecretory variant the content of cytokines decreases almost 4-5 times. Against a background of the intake of bacterial lysates with the edematous variant the activity and content of the factors of local immunity rises somewhat, but their level remains lower than the indicators of the control group, with the hypersecretory variant their level reaches the indicators of healthy children. The results of the research enable to recommend bacterial lysates to be used in multimodality therapy of patients afflicted with the hypersecretory variant of croup that will promote a more rapid normalization of the systemic inflammatory reaction and a stimulation of the production and activation of the factors of local immunity in sick children.
\end{abstract}

Key words: viral croup, cytokines, local immunity, children, bacterial lysates.

National Medical University (Kharkiv)

Рецензент - проф. О.К. Колоскова

Buk. Med. Herald. - 2013. - Vol. 17, № 2 (66). - P. 51-55

Надійшла до редакції 21.01.2013 року

(С) Т.О. Кірсанова, С.В. Кузнєцов, М.С. Зіміна, Е.В. Супрун, 2013

УДК 616.379-008.604-092:612.018

\section{Х.Ф. Кехіопуло \\ ОЦНКА ЕФЕКТИВНОСТІ РІЗНИХ ТЕРАПЕВТИЧНИХ ПІДХОДІВ ДО КОРЕКЦІЇ ПОКАЗНИКІВ СИСТЕМ КОАГУЛЯЦІЇ І ФІБРИНОЛІЗУ, МАРКЕРІВ ЗАПАЛЕННЯ У ХВОРИХ НА ЦУКРОВИЙ ДІАБЕТ 2-ГО ТИПУ 3 ОЖИРІННЯМ}

Український науково-практичний центр ендокринної хірургії, трансплантації ендокринних органів і тканин МО3 України, м. Київ

\begin{abstract}
Резюме. Досліджено стан систем коагуляції і фібринолізу, рівень прозапальних маркерів у пацієнтів із цукровим діабетом (ЦД) 2-го типу і ожирінням у взаємозв'язку 3 чинниками ризику розвитку серцевосудинних захворювань, а також ефективність різних терапевтичних підходів до корекції порушених показників запалення, гемостазу і фібринолізу. Встановлено, що раціональне гіпокалорійне харчування, заходи 3 модифікації способу життя і прийом метформіну сприяють статистично вірогідному зниженню маси тіла, про-
\end{abstract}

Вступ. Цукровий діабет (ЦД) 2-го типу в поєднанні з вісцеральним ожирінням характеризується протромбогенними змінами гемостазу i фібринолізу, станом хронічного підгострого системного запалення, що значно збільшує ризик виникнення серцево-судинних захворювань (CC3) $[1,5]$. Основою терапії, скерованої на запобігання прогресування ЦД 2-го типу і розвитку $\mathrm{CC} 3$, є вплив на інсулінорезистентність. Провідне місце серед фармакологічних засобів, які володіють позитивним впливом на чутливість тканин до інсуліну, посідають бігуаніди (метформін) [6]. те $є$ неефективними для корекції прозапальних і прокоагулянтних порушень. Комбінована терапія, яка включає прийом метформіну і ліраглутиду, сприяє більш значущому зниженню маси тіла порівняно з монотерапією мет- форміном і сприяє поліпшенню параметрів ліпідного обміну, корекції асоційованих із ЦД прозапальних порушень і недостатності фібринолізу.

Ключові слова: цукровий діабет 2-го типу, ожиріння, показники коагуляції i фібринолізу, маркери запалення, метформін, ліраглутид.

Крім антигіперглікемічного ефекту, метформін має виражену антиатерогенну, антитромбогенну, кардіопротективну і протизапальну дію [8]. Ліраглутид належить до аналогів глюкагоноподібного пептиду-1 (ГПП-1) з послідовністю амінокислот, на 97 \% гомологічною людському ГПП-1, який зв'язується з ГПП-1-рецепторами і активує їх [7]. Враховуючи широкий спектр фармакологічних ефектів, великий інтерес представляє вивчення ефективності застосування метформіну у вигляді монотерапії, а також у поєднанні з ліраглутидом у пацієнтів з ЦД 2-го типу з ожирінням на тлі 
інсулінорезистентності, прозапальних і протромбогенних порушень.

Незважаючи на значну поширеність ЦД 2-го типу, ожиріння і СС3, патогенетичні механізми, які лежать в основі прозапального і прокоагулянтного станів при цих патологіях, недостатньо вивчені. Крім того, відсутні загальноприйняті підходи до діагностики і лікування запальних i гіперкоагуляційних порушень, поєднаних із ЦД 2-го типу і ожирінням. Все це свідчить про актуальність проблеми вивчення стану згортальної i протизгортальної систем, а також встановлення ефективності різних терапевтичних підходів для корекції наявних при ЦД 2-го типу прозапальних i прокоагулянтних порушень. Такі дослідження можуть надати додаткову інформацію при розробці алгоритмів ранньої доклінічної діагностики і корекції зазначених порушень з метою зниження загального кардіометаболічного ризику, запобігання або максимально тривалого відтермінування маніфестації ускладнень ЦД 2-го типу і ССЗ.

Мета дослідження. Вивчити стан систем коагуляції і фібринолізу, рівень прозапальних маркерів у хворих на ЦД 2-го типу з ожирінням у взаємозв'язку з чинниками ризику розвитку СС3, а також оцінити ефективність різних терапевтичних підходів до корекції порушених показників запалення, гемостазу і фібринолізу.

Матеріал і методи. У відкрите, проспективне, рандомізоване дослідження тривалістю шість місяців включено 56 пацієнтів, які відповідали таким критеріям: вік від 45 до 65 років; тривалість ЦД 2-го типу від 3 до 10 років; індекс маси тіла (IMT) - від 31 до 39 кг/м² у поєднанні з будьякими двома 3 наведених ознак, а саме рівень тригліцеридів (ТГ) $\geq 1,7$ ммоль/л; вміст холестерину ліпопротеїнів високої щільності (XC ЛПВЩ) < 1,29 ммоль/л; систолічний артеріальний тиск (САТ) $\geq 130$ або діастолічний артеріальний тиск (ДАТ) $\geq 85$ мм рт.ст., або здійснювана антигіпертензивна терапія. Критерії виключення: ЦД 1-го типу; гіпотиреоз; наявність в анамнезі коагулопатій, гострого порушення мозкового кровообігу, інфаркту міокарда, тромбоемболії; замісна гормональна терапія; куріння.

Пацієнти $(\mathrm{n}=56)$ були розподілені на дві групи - основну і контрольну. У контрольній групі $(n=28)$ здійснювали заходи 3 модифікації способу життя (раціональне харчування, фізичні навантаження) на тлі прийому метформіну з поступовою титрацією дози до 2000 мг на добу (по 1000 мг двічі на день після їжі). В основній групі пацієнтів $(\mathrm{n}=28)$, поряд 3 аналогічною терапією додатково призначали підшкірні ін'єкції ліраглутиду (препарат Віктоза) 1 раз на добу незалежно від прийому їі. Початкова доза препарату становила 0,6 мг/добу, через тиждень дозу збільшували до 1,2 мг/добу. 356 осіб, включених у дослідження, повністю курс лікування завершили 48 пацієнтів. Вісім пацієнтів (шість 3 основної і два - 3 контрольної) передчасно вибули 3 дослідження через відмову від подальшої участі.
У пацієнтів вивчали скарги, анамнез основного захворювання (ЦД 2-го типу). Фізикальне обстеження включало вимірювання антропометричних параметрів (ріст, маса тіла, окружність талії OT, обчислення IMT), АТ. 3 метою оцінки стану вуглеводного обміну проводилося визначення глікемії глюкозооксидазним методом, глікозильованого гемоглобіну та імунореактивного інсуліну (IPI) 3 використанням стандартних наборів реактивів «Рио-Инс-ПГ 125І». Показники ліпідного обміну: вміст загального холестерину - ЗХС, ТГ і ХС ЛПВЩ у сироватці крові визначали імуноферментним методом за допомогою діагностичних наборів фірми «Нuman» (Німеччина) на біохімічному поліаналізаторі «Нuman» (Німеччина). Piвень ХС ЛПНЩ обчислювали за формулою Friedwald i співавт. Непрямий показник інсулінорезистентності - індекс HOMA-IR (Homeostasis Model Assessment - Insulin Resistance) - розраховували за формулою: глюкоза натще (ммоль/л) х інсулін натще (Од/л) / 22,5.

Для аналізу системи гемостазу визначали показники активованого часткового тромбопластинового часу (АЧТЧ), тромбінового часу (ТЧ), рівень фібриногену плазми, активність фактора VIII (FVIII) за допомогою наборів реактивів фірми «Human» (Німеччина).

Показники фібринолітичної системи - рівень активності активатора плазміногена тканинного типу (t-PA), антитромбіну III і показник активності антикоагулянтної системи протеїн С, визначення ристоцитин кофакторної активності фактора Віллебранда (vWF) встановлювали імуноферментним методом ELISA $з$ використанням наборів реактивів фірми «Technoclone» (Австрія). Як прозапальні маркери досліджували рівні фібриногену і C-реактивного білка (СРБ). Рівень адипонектину визначали 3 допомогою набору «Biovendor Human Adiponectin ELISA». Для аналізу системи фібринолізу проводили визначення активного антигену інгібітору активатора плазміногена-1 (ІАП-1) та активності активатора плазміногена тканинного типу (t-PA). Аналіз здійснювали твердофазним імуноферментним та імунохромогенним методами.

Статистичний аналіз отриманих результатів проводили 3 допомогою програм Microsoft Office Excel 2007 (Microsoft Corp., США) i Portable Statistica 8 (StatSoft, Inc., США). Характер розподілу всіх ознак оцінювали за допомогою критеріїв Шапіро-Уілка і Колмогорова-Смирнова. У зв'язку з тим, що основна маса ознак мала розподіл, який відрізнявся від нормального, результати представлені у вигляді значень медіан і інтерквартильних інтервалів (Ме [25; 75]). Враховуючи невеликі розміри вибірок, а також той факт, що більшість аналізованих ознак мала розподіл, відмінний від нормального, для статистичного аналізу отриманих результатів використовували непараметричні статистичні тести. Порівняння двох незалежних груп за безперервними ознаками здійснювали за допомогою U-тесту Манна- 
Уїтні, а двох залежних груп - за допомогою тесту Вілкоксона. Оцінка взаємозв'язку ознак проводилася з використанням методу рангової кореляції Спірмена ( $\mathrm{r}$ - коефіцієнт кореляції). Критичний рівень значущості при перевірці статистичних гіпотез приймався за 0,05 .
Результати дослідження та їх обговорення. При первинному обстеженні прокоагулянтні порушення встановлені в абсолютної більшості пацієнтів із ЦД 2-го типу і вісцеральним ожирінням (94,6 \%), при цьому в 64,3 \% обстежених ці порушення носили поєднаний характер, торкаючись

Таблиця 1

Динаміка лабораторних показників у групі комбінованої терапії (n=22)

\begin{tabular}{|c|c|c|c|c|}
\hline Показник & До лікування & Через 6 місяців терапії & $\mathrm{W}$ & $\mathrm{P}$ \\
\hline ЗХС, ммоль/л & $6,9[6,1 ; 7,5]$ & $6,1[5,4 ; 7,3]$ & 81,5 & $<0,05$ \\
\hline ХС ЛПНЩ, ммоль/л & $4,62[3,84 ; 5,19]$ & $3,81[3,25 ; 4,89]$ & 65,0 & $<0,05$ \\
\hline ХС ЛПВЩ, ммоль/л & $1,18[1,02 ; 1,54]$ & $1,22[1,03 ; 1,66]$ & 129,5 & $>0,05$ \\
\hline ТГ, ммоль/л & $2,3[1,2 ; 2,8]$ & $1,4[1,1 ; 2,3]$ & 68,0 & $<0,05$ \\
\hline Глікемія натще, ммоль/л & $9,1[7,1 ; 10,9]$ & $5,9[5,1 ; 7,0]$ & 17,5 & $<0,001$ \\
\hline Інсулін, Од/л & $19,3[12,8 ; 27,8]$ & $12,6[9,9 ; 20,7]$ & 11,0 & $<0,001$ \\
\hline НОМА-ІR & $5,09[3,14 ; 7,13]$ & $3,11[2,27 ; 4,53]$ & 6,5 & $<0,001$ \\
\hline АЛТ, Од/л & $32,6[21,8 ; 41,3]$ & $21,9[16,1 ; 26,2]$ & 17,0 & $<0,001$ \\
\hline АСТ, Од/л & $23,4[20,1 ; 37,8]$ & $19,8[17,2 ; 23,8]$ & 27,5 & $<0,05$ \\
\hline
\end{tabular}

Таблиця 2

Динаміка лабораторних показників у групі монотерапії метформіном (n=26)

\begin{tabular}{|c|c|c|c|c|}
\hline Показник & До лікування & Через 6 місяців терапії & $\mathrm{W}$ & $\mathrm{p}$ \\
\hline ЗХС, ммоль/л & $6,8[6,0 ; 7,6]$ & $6,0[5,3 ; 7,4]$ & 81,5 & $<0,05$ \\
\hline ХС ЛПНЩ, ммоль/л & $4,67[3,72 ; 5,11]$ & $3,74[3,27 ; 4,81]$ & 64,0 & $<0,05$ \\
\hline ХС ЛПВЩ, ммоль/л & $1,17[1,04 ; 1,57]$ & $1,24[1,09 ; 1,64]$ & 128,5 & $>0,05$ \\
\hline ТГ, ммоль/л & $2,4[1,3 ; 2,7]$ & $1,5[1,2 ; 2,4]$ & 66,0 & $<0,05$ \\
\hline Глікемія натще, ммоль/л & $8,9[6,1 ; 10,7]$ & $5,9[5,6 ; 6,9]$ & 14,5 & $<0,001$ \\
\hline Інсулін, Од/л & $18,7[12,9 ; 26,8]$ & $13,1[9,7 ; 21,1]$ & 9,0 & $<0,001$ \\
\hline НОМА-ІR & $5,07[3,11 ; 7,11]$ & $3,18[2,27 ; 4,42]$ & 5,5 & $<0,05$ \\
\hline АЛТ, Од/л & $36,2[21,6 ; 43,8]$ & $23,8[18,1 ; 27,2]$ & 16,0 & $<0,001$ \\
\hline АСТ, Од/л & $24,9[20,2 ; 38,1]$ & $18,1[16,8 ; 28,4]$ & 27,5 & $<0,05$ \\
\hline
\end{tabular}

Таблиця 3

Динаміка показників гемостазу у групі монотерапії метформіном (n=22)

\begin{tabular}{|c|c|c|c|}
\hline Показник & До лікування & $\begin{array}{c}\text { Через } 12 \text { місяцев тера- } \\
\text { пії }\end{array}$ & W \\
\hline Активність FVIII, \% & $73,8[61,7 ; 88,4]$ & $106,0[83,2 ; 118,0]$ & 1,0 \\
\hline Активність vWF, \% & $112,0[97,0 ; 130,0]$ & $129,5[100,1 ; 183,5]$ & 25,0 \\
\hline Активність ІАП-1, Од/мл & $18,2[10,63 ; 33,81]$ & $14,9[8,62 ; 29,03]$ & 35,0 \\
\hline Активність t-РА, Од/мл & $0,04[0,01 ; 0,07]$ & $0,07[0,03 ; 0,11]$ & 115,0 \\
\hline Активність антитромбіну III, \% & $99,2[89,1 ; 106,4]$ & $95,4[91,0 ; 102,5]$ & 70,0 \\
\hline Активність системи протеїну С & $0,87[0,74 ; 0,98]$ & $0,84[0,68 ; 0,97]$ & 58,0 \\
\hline
\end{tabular}


Таблиця 4

Динаміка показників гемостазу у групі комбінованої терапії (n=22)

\begin{tabular}{|c|c|c|c|c|}
\hline Показник & До лікування & Через 6 місяців терапії & $\mathrm{W}$ & $\mathrm{p}$ \\
\hline Активність FVIII, \% & $76,7[62,1 ; 92,6]$ & $82,0[71,0 ; 105,0]$ & 97,5 & $>0,05$ \\
\hline Активність vWF, \% & $114,0[98,0 ; 132,0]$ & $132,6[96,5 ; 139,8]$ & 120,0 & $>0,05$ \\
\hline Активність ІАП-1, Од/мл & $20,4[8,39 ; 32,09]$ & $9,7[5,19 ; 17,94]$ & 38,0 & $<0,001$ \\
\hline Активність t-РА, Од/мл & $0,08[0,03 ; 0,14]$ & $0,08[0,02 ; 0,11]$ & 174,0 & $>0,05$ \\
\hline Активність антитромбіну III, \% & $98,3[87,6 ; 107,9]$ & $92,5[82,4 ; 101,0]$ & 116,0 & $>0,05$ \\
\hline Активність системи протеїну С & $0,82[0,64 ; 0,94]$ & $0,89[0,73 ; 0,98]$ & 86,5 & $<0,05$ \\
\hline
\end{tabular}

відразу декількох ланок згортальної системи крові. До найчастіших порушень гемостазу належали підвищення активності ІАП-1 (87,5 \%), що відображує недостатність фібринолізу; підвищення активності чинника коагуляції VIII $(53,6 \%) 3$ активацією зовнішнього каскаду згортання крові, і недостатність антикоагулянтної системи протеїну C (23,2 \%). Хронічне підгостре системне запалення в пацієнтів із ЦД 2-го типу з вісцеральним ожирінням проявлялося вірогідним підвищенням концентрації маркерів запалення - фібриногену і СРБ, а також зниженням рівня адипонектину. Вираженість прозапальних і прокоагулянтних порушень у хворих на ЦД 2-го типу 3 вісцеральним ожирінням асоційована 3 антропометричними i біохімічними маркерами ожиріння, що вказує на поєднаний і взаємозв'язаний розвиток прокоагулянтного і прозапального станів при прогресуванні ожиріння та інсулінорезистентності [3].

Після шести місяців лікування в обох терапевтичних групах - основній і контрольній - спостерігалася статистично вірогідна динаміка антропометричних показників (маса тіла, IMT i ОТ). Однак у групі комбінованої терапії, що включала прийом метформіну і ліраглутиду, відзначалася більш виражена динаміка зазначених показників. Так, у групі комбінованої терапії медіана зниження маси тіла становила 9,4 кг $(9,2 \%)$, IMT - 3,2 кг/ $\mathrm{m}^{2}(8,7 \%)$, а ОT - $11 \mathrm{~cm}$ (8,9 \%). У групі монотерапії метформіном відповідні медіани становили 0,5 кг $(0,3 \%), 0,3$ кг/м $(5,7 \%)$ і 0,9 см $(0,6 \%)$. Основна і контрольна групи пацієнтів значно відрізнялися за розподілом обстежених, які досягнули різного ступеня зниження маси тіла. У групі комбінованої терапії клінічно значущого зниження маси тіла - не менше $5 \%$ - досягнуло 18 (81,8\%) пацієнтів, тоді як у групі монотерапії метформіном - лише 4 $(15,4 \%)$. Отримані нами результати свідчать про вірогідно більшу ефективність комбінованої терапії з призначенням ліраглутиду для зниження маси тіла і маси вісцерального жиру порівняно 3 монотерапією метформіном. До певної міри це підтверджує дані літератури про вплив метформіну і ліраглутиду на масу і композиційний склад тіла, а також може бути наслідком більшої прихильності пацієнтів, які отримують медикаменто- зне лікування, до дотримання рекомендацій 3 харчування і фізичних навантажень $[3,9]$.

Терапія метформіном з ліраглутидом призвела до вірогідного поліпшення низки біохімічних параметрів (табл. 1). Найбільш значимі позитивні зміни відзначалися 3 боку всіх досліджуваних показників вуглеводного обміну - глікемії натще, концентрації інсуліну і індексу HOMA-IR. Ці результати досить очікувані, оскільки безпосередньо відображають основні фармакологічні ефекти метформіну і ліраглутиду.

У групі монотерапії метформіном після закінчення шести місяців дослідження нами виявлено статистично вірогідне зниження концентрації інсуліну в сироватці крові і показника інсулінорезистентності HOMA-IR, що вказує на зменшення інсулінорезистентності і компенсаторної гіперінсулінемії (табл. 2). Показники терапії в обох групах хворих супроводжувалися поліпшенням ліпідного спектра крові: відзначалося статистично вірогідне зниження рівнів ЗХС, ХС ЛПНЩ i ТГ, а також тенденція до підвищення концентрації ХС ЛПВЩ. Отже, аналіз отриманих результатів в обох групах пацієнтів свідчить про ефективність проведеної терапії для профілактики прогресування інсулінорезистентності, яка є патогенетичною основою ЦД 2-го типу, а також для корекції вже наявних порушень вуглеводного і ліпідного обміну.

3 двох досліджених нами маркерів системного запалення - фібриногену і СРБ - більш виражена динаміка відзначалася лише стосовно останнього. У групі комбінованої терапії після закінчення лікування відзначалося статистично вірогідне зниження концентрації СРБ на 2,48 мг/л $(48,2 \%)(p<0,05)$. Слід зазначити, що при проведенні нами кореляційного аналізу значимих взаємозв'язків між зниженням рівня СРБ у крові і зміною антропометричних параметрів і показників вуглеводного обміну не виявлено, тобто протизапальний ефект препаратів не залежав від зниження маси тіла. 3 іншого боку, у групі монотерапії метформіном вірогідної зміни рівня СРБ не виявлено, попри те, що відзначалося зниження медіани цього показника на 14,6 \%.

На початку дослідження найбільш інформативними показниками коагулограми, які дозволи- 
ли встановити вже на перших етапах обстеження пацієнтів наявність у них прокоагулянтних і прозапальних змін, виявилися АЧТЧ і концентрація фібриногену в плазмі крові. Через шість місяців лікування в обох групах не спостерігалося значимих змін цих показників, проте відзначалася тенденція до подовження медіани АЧТЧ на 3,2 і $3,5 \%$ в основній і контрольній групах відповідно. Медіани концентрації фібриногену у двох групах змінилися різнонаправлено: в основній групі вона знизилася на $1,2 \%(\mathrm{p}<0,05)$, а в контрольній підвищилася на $0,7 \%(\mathrm{p}<0,05)$.

Крім того, у групі комбінованої терапії нами виявлено статистично вірогідне підвищення протромбінового індексу (з 87,5 [83,0; 94,5] до 94,5 $[90,5 ; 102,0], \mathrm{p}<=0,05)$. Слід, однак, врахувати, що цей показник у всіх пацієнтів як початково, так і після шести місяців лікування перебував у межах референсного інтервалу. У зв'язку з цим можна припустити, що підвищення протромбінового індексу на тлі зниження маси тіла і комбінованої терапії пов'язане не стільки $з$ активацією зовнішнього шляху згортання, скільки 3 поліпшенням функціонального стану печінки, враховуючи, що проведене лікування супроводжувалося значимим зниженням рівня трансаміназ, а також той факт, що протромбіновий тест безпосередньо відображує білковосинтетичну функцію печінки. При проведенні кореляційного аналізу виявлена негативна асоціація зміни протромбінового індексу зі зміною концентрації СРБ $(\mathrm{r}=-0,42 ; \mathrm{p}<0,05)$, тобто величина індексу збільшувалася при подальшому зменшенні запального процесу.

У літературі наводяться чисельні дані, що вказують на позитивний вплив зниження маси тіла на поліпшення параметрів гемостазу і фібринолізу [2, 4]. Проте у проведеному дослідженні нами не отримано жодних статистично вірогідних позитивних змін параметрів згортальної і протизгортальної систем крові в групі монотерапії метформіном (табл. 3), що, очевидно, можна пояснити недостатнім зниженням маси тіла в цій групі пацієнтів. Крім того, на тлі монотерапії метформіном відзначалося значиме підвищення активностей FVIII і vWF, що може вказувати на погіршення ендотеліальної функції. Загалом можна констатувати той факт, що монотерапія метформіном виявилася неефективною відносно корекції виявлених у пацієнтів прокоагулянтних i прозапальних порушень, асоційованих з інсулінорезистентністю.

Навпаки, при аналізі динаміки прокоагулянтного стану в групі комбінованої терапії спостерігалися позитивні зміни. Найбільш значимі поліпшення відзначалися відносно ІАП-1 (табл. 4). Терапія метформіном з ліраглутидом призвела до зниження медіани активності ІАП-1 на 11,4 Од/мл (54\%, p<0,005), що свідчить про виражене і значиме поліпшення фібринолізу і зниження протромбогенного потенціалу. Слід зазначити, що зниження ІАП-1 виявилося позитивно асоційованим із поліпшенням антропометричних параметрів, зокрема, маси тіла $(\mathrm{r}=0,52 ; \mathrm{p}<0,05)$,
IMT $(\mathrm{r}=0,53 ; \mathrm{p}<0,01)$ i OT $(\mathrm{r}=0,51 ; \mathrm{p}<0,05)$, тобто нормалізація фібринолізу, принаймні, частково була опосередкована зниженням маси жирової тканини в організмі. Крім того, зниження активності ІАП-1 вірогідно асоціювалося зі зниженням концентрації СРБ (r=0,49; $<<0,05)$, що свідчить про поліпшення фібринолізу і зменшення запалення на тлі комбінованої терапії. Взаємозв'язку між зниженням активності ІАП-1 і поліпшенням параметрів вуглеводного обміну не отримано.

Після закінчення комбінованого лікування спостерігалася тенденція до зниження активності FVII (медіана активності FVII знизилася на 3,6 \%, $\mathrm{p}>0,05)$, що, можливо, відображує деяке зменшення надмірної активації зовнішнього шляху коагуляції, яка спостерігалася в пацієнтів із ЦД 2-го типу до початку терапії.

Комбінована терапія також супроводжувалася статистично значимим підвищенням активності антикоагулянтної системи протеїну C (медіана активності цієї системи підвищилася на 6,1 \%, $\mathrm{p}<0,05)$, недостатність якої виявлена на початковому етапі дослідження. Цей факт свідчить про позитивну тенденцію в динаміці функціонування протизгортальної системи на тлі здійснюваного лікування. У відношенні іншого досліджуваного нами антикоагулянта - AT III -виявлена тенденція до деякого зниження його активності (медіана активності знизилася на 9,2 \%, p>0,05). Оцінюючи виявлене на початковому етапі дослідження відносне підвищення активності АT III, а також враховуючи, що всі зміни перебували в рамках прийнятого референсного інтервалу для показника, цей факт можна інтерпретувати як позитивний, що відображає поліпшення рівноваги між згортальною і протизгортальною системами крові на тлі проведення комбінованої терапії із застосуванням метформіну та ліраглутиду.

Через шість місяців лікування в групі комбінованої терапії виявлено статистично вірогідне підвищення рівня адипонектинемії $(14,89$ [7,72; 17,61] мкг/мл проти 9,79 [6,81; 16,97] мкг/мл, $\mathrm{p}<0,05)$; підвищення медіани концентрації адипонектину склало 3,46 мкг/мл $(31,8$ \%), що відображує зниження загального кардіометаболічного ризику на тлі здійснюваного лікування. Зміна рівня адипонектину не залежала від зниження маси тіла, IMT і ОT, проте негативно корелювала зі зміною глікемії натще $(\mathrm{r}=-0,58 ; \mathrm{p}<0,05)$, тобто частково була взаємозв'язана 3 основним фармакологічним ефектом препаратів. У контрольній групі пацієнтів значимої зміни цього показника не відмічено, хоча спостерігалася тенденція до підвищення медіани його концентрації на 16,7 \% $(12,35[7,67 ; 15,74]$ мкг/мл проти $10,64[7,35$; $18,07]$ мкг/мл, $\mathrm{p}>0,05)$.

Підводячи підсумок проведеного порівняльного аналізу ефективності двох підходів - комбінованого і монотерапії метформіном - можна дійти висновку про більшу ефективність лікування ЦД 2-го типу і корекції асоційованих 3 ним прозапальних і прокоагулянтних порушень шляхом призначення препаратів бігуанідів та інгібі- 
торів ГПП-1. Комбінована терапія 3 прийомом метформіну та ліраглутиду впродовж тривалого періоду добре переносилася, була безпечною i дозволила ефективно впливати на ключові ланки патогенезу ЦД 2-го типу. Крім того, комбіноване лікування сприяло поліпшенню параметрів ліпідного обміну, корекції асоційованих із ЦД прозапальних порушень (концентрацій СРБ і адипонектину) і недостатності фібринолізу (підвищення активності ІАП-1). На тлі прийому метформіну та ліраглутиду також відмічені позитивні тенденції з боку інших виявлених прокоагулянтних порушень (вкорочення АЧТЧ, гіперфібриногенемія, недостатність антикоагулянтної системи протеїну C), які, проте, не досягли статистичної значимості. Можливо, що для досягнення більш вірогідних позитивних змін цих параметрів необхідно проведення дослідження 3 використанням більшого об'єму вибірки і тривалішим періодом терапії. Проте результати, продемонстровані нами в групі комбінованої терапії після закінчення курсу лікування, вказують на вірогідне зниження тромбогенного потенціалу плазми і вираженості хронічного системного запалення, що, у сукупності зі зниженням маси тіла, інсулінорезистентності і поліпшенням показників ліпідного обміну, сприяє зниженню серцево-судинного і загального кардіометаболічного ризику, а також поліпшенню прогнозу у хворих на ЦД 2-го типу з ожирінням.

\section{Висновки}

1. Терапія, що включає раціональне гіпокалорійне харчування, заходи 3 модифікації способу життя і прийом метформіну, сприяє статистично значимому зниженню маси тіла, проте $є$ неефективною для корекції прозапальних і прокоагулянтних порушень, які спостерігаються при цукровому діабеті 2-го типу і не дозволяе запобігти прогресуванню інсулінорезистентності і асоційованих $з$ нею порушень.

2. Комбінована терапія, що включає прийом метформіну і ліраглутиду, сприяе більш значимому зниженню маси тіла, порівняно 3 монотерапією метформіном і дозволяє ефективніше впливати на ключові ланки патогенезу цукрового діабету 2-го типу - вісцеральне ожиріння та інсулінорезистентність, а також сприяє поліпшенню параметрів ліпід- ного обміну, корекції асоційованих з цукровим діабетом прозапальних порушень (концентрацій Cреактивного білка і адипонектину) і недостатності фібринолізу (підвищення активності ІАП-1).

Перспективи подальших досліджень. Перспективним є розроблення схеми ранньої доклінічної діагностики, вдосконалення підходів до лікування прокоагулянтних і прозапальних порушень у хворих на ЦД 2-го типу з ожирінням.

\section{Література}

1. Братусь В.В. Ожирение, инсулинорезистентность, метаболический синдром: фундаментальные и клинические аспекты / В.В. Братусь, Т.В. Талева, В.А. Шумаков. - К.: Четверта хвиля, 2009. - 416 с.

2. Уровни маркеров тромбинемии и тромбообразования у больных эссенциальной артериальной гипертензией с кардиоваскулярным риском / В.Н. Крамарева, В.Г. Гриценко, И.Н. Колесникова [и др.] // Наук. вісн. Нац. мед. унту імені О.О.Богомольця. - 2009. - № 4. - С. 177-180.

3. Alessi M.C. Plasminogen activator inhibitor-1, adipose tissue and insulin resistance / M.C. Alessi, M. Poggi, I. Juhan-Vague // Curr. Opin. Lipidol. - 2007. - Vol. 18, № 3. P. 240-245.

4. Diabetes mellitus and thrombosis / N. Vazzana, P. Ranalli, C. Cuccurullo, G. Davi // Thromb. Res. - 2012. Vol. 129, № 3. - P. 371-377.

5. Hyperglycemia is associated with enhanced thrombin formation, platelet activation, and fibrin clot resistance to lysis in patients with acute coronary syndrome / A. Undas, I. Wiek, E. Stepien [et al.] // Diabetes Care. - 2008. Vol. 31, № 8. - P. 1590-1595.

6. Inzucchi S.E. Management of hyperglycaemia in type 2 diabetes: a patient-centered approach. Position statement of the American Diabetes Association (ADA) and the European Association for the Study of Diabetes (EASD) / S.E. Inzucchi, R.M. Bergenstal // Diabetologia. - 2012. Vol. 55, № 6. - P. 1577-1596.

7. Liraglutide once a day versus exenatide twice a day for type 2 diabetes: a 26-week randomised, parallel-group, multinational, open-label trial (LEAD-6) / J.B. Buse, J. Rosenstock, G. Sesti [et al.] // Lancet. - 2009. - Vol. 374 (9683). P. 39-47.

8. Metformin associated with lower cancer mortality in type 2 diabetes / G.W.D. Landman, N. Kleefstra, K.J.J. van Hateren [et al.] // Diabetes Care. - 2010. - Vol. 33, № 2. P. 322-326.

9. Pinelli N.R. Efficacy and safety of long-acting glucagonlike peptide-1 receptor agonists compared with exenatide twice daily and sitagliptin in type 2 diabetes mellitus: a systematic review and meta-analysis / N.R. Pinelli, K.M. Hurren // Ann. Pharmacother. - 2011. - Vol. 45, № 7-8. - P. 850-860.

\section{ОЦЕНКА ЭФФЕКТИВНОСТИ РАЗЛИЧНЫХ ТЕРАПЕВТИЧЕСКИХ ПОДХОДОВ К КОРРЕКЦИИ ПОКАЗАТЕЛЕЙ СИСТЕМ КОАГУЛЯЦИИ И ФИБРИНОЛИЗА, МАРКЕРОВ ВОСПАЛЕНИЯ У БОЛЬНЫХ САХАРНЫМ ДИАБЕТОМ 2-ГО ТИПА С ОЖИРЕНИЕМ}

\section{К.Ф. Кехиопуло}

Резюме. В работе изучено состояние систем коагуляции и фибринолиза, уровень провоспалительных маркеров у пациентов с сахарным диабетом (СД) 2-го типа и ожирением во взаимосвязи с факторами риска развития сердечно-сосудистых заболеваний, а также установлена эффективность различных терапевтических подходов к коррекции нарушенных показателей воспаления, гемостаза и фибринолиза. Установлено, что терапия, включающая рациональное гипокалорийное питание, мероприятия по модификации образа жизни и прием метформина, способствует статистически достоверному снижению массы тела, однако является неэффективной для коррекции провоспалительных и прокоагулянтных нарушений. Комбинированная терапия, которая включает прием метформина и лираглутида, способствует более значимому снижению массы тела в сравнении с монотерапией метформином и 
способствует улучшению параметров липидного обмена, коррекции ассоциированных с СД провоспалительных нарушений и недостаточности фибринолиза.

Ключевые слова: сахарный диабет 2-го типа, ожирение, показатели коагуляции и фибринолиза, маркеры воспаления, метформин, лираглутид.

\title{
AN EVALUATION OF THE EFFICACY OF THERAPEUTIC APPROACHES TO CORRECTING THE INDICES OF THE SYSTEMS OF COAGULATION AND FIBRINOLYSIS, INFLAMMATION MARKERS IN PATIENTS WITH DIABETES MELLITUS OF TYPE 2 WITH OBESITY
}

\section{K.F. Kehiopulo}

Abstract. The paper investigates the state of the systems of coagulation and fibrinolysis, the level of proinflammatory markers in patients with diabetes mellitus (DM) of type 2 and obesity, in a correlation with risk factors of the development of cardiovascular diseases, as well as the efficacy of different therapeutic approaches to a correction of disturbed indicators of inflammation, hemostasis and fibrinolysis. It has been established that rational hypocaloric feeding, measures of a modification of the life style and the intake of metformin contribute to a statistically significant body weight loss, however, they are ineffective for correcting proinflammatory and procoagulant disorders. Combined therapy, including the intake of metformin and liraglutide is condurive to a more significal reduction of the body weight as compared with metformin monotherapy and contributes to an improvement of the parameters of lipid metabolism, a correction of proinflammatory disturbances and fibrinolytic insufficiency associated with DM.

Key words: type 2 diabetes mellitus, obesity, coagulation and fibrinolytic parameters, markers of inflammation, metformin, liraglutide.

Ukrainian Scientific-Practical Centre of Endocrine Surgery, Transplantation of Endocrine Organs and Tissues of Ukraine`s MHP (Kyiv)

\author{
С.Е. Косілова
}

\section{ВПЛИВ ПОРУШЕНЬ СТАНУ ЩИТОПОДІБНОЇ ЗАЛОЗИ НА РЕПРОДУКТИВНУ ФУНКЦІЮ ЖІНОЧОГО ОРГАНІЗМУ}

Буковинський державний медичний університет, м. Чернівці

\begin{abstract}
Резюме. У статті наведені аспекти порушення функції репродуктивної системи в жінок на тлі захворювань щитоподібної залози. Виявлено, що частота виникнення розладів репродуктивної системи є залеж-
\end{abstract}

Вступ. Щитоподібна залоза як орган внутрішньої секреції продукує гормони тироксин $\left(\mathrm{T}_{4}\right)$ та трийодтиронін $\left(\mathrm{T}_{3}\right)$. Рівновага в системі аденогіпофіз - щитоподібна залоза відбувається внаслідок взаємодії тропних гормонів гіпофіза та ефекторних ендокринних залоз $[1,2,5]$. Збільшення щитоподібної залози, навіть за відсутності клінічних ознак, $є$ ранньою ознакою внутрішнього неблагополуччя, і нерідко хоча б мінімальної недостатності тиреоїдних гормонів [3, 4, 6, 7]. Недостатня функція щитоподібної залози супроводжується розладами в гіпоталамо-гіпофізарній системі, що призводить до порушень менструальної та репродуктивної функції жінки $[5,6,7,8]$. Механізм впливу гіпотиреозу на репродуктивну систему пояснюється тим, що в умовах дефіциту тиреоїдних гормонів підсилюється ріст тиреотрофів, які продукують підвищену кількість тиреот- ною від перебігу захворювань ендокринної системи i пов'язаних 3 нею гормональних порушень.

Ключові слова: щитоподібна залоза, репродуктивна система, непліддя.

ропного гормону (ТТГ), пригнічується функція гіпофіза, що синтезує ЛГ, знижується реактивність рецепторів гіпофіза по відношенню до пригнічення дії естрагенів на ФСГ, що призводить до гіперфункції останнього $[1,2,6,9]$.

Враховуючи однонаправлену зміну рівнів ТТГ і пролактину (ПРЛ), можливим $є$ поява змін у репродуктивній системі при патології щитоподібної залози [8]. А надлишкова секреція ПРЛ є причиною порушень менструальної і генеративної функції більш ніж у 50-75 \% випадків $[3,4,8]$.

Явна гіперпролактинемія діагностується при аденомах гіпофіза, а в клінічній практиці частіше трапляється періодична і прихована гіперпролактинемія. Існує дві форми пролактину: з низькою і високою молекулярною масою. Останній здійснює біологічний вплив. Усі тест-системи визначають рівень загального ПРЛ, тому невідомо на- 